\title{
Pregnancy modulates the allergen-induced cytokine production differently in allergic and non-allergic women
}

Martina Abelius, Malin J edenfalk, J an Ernerudh, Camilla J anefjord, Göran Berg, Leif Matthiesen and Maria J enmalm

The self-archived postprint version of this journal article is available at Linköping University Institutional Repository (DiVA):

http:// urn.kb.se/ resolve?urn=urn:nbn:se:liu:diva- 144152

N.B.: When citing this work, cite the original publication.

Abelius, M., J edenfalk, M., Ernerudh, J., J anefjord, C., Berg, G., Matthiesen, L., J enmalm, M., (2017), Pregnancy modulates the allergen-induced cytokine production differently in allergic and non-allergic women, Pediatric Allergy and Immunology, 28(8), 818-824. https:// doi.org/ 10.1111/ pai.12802

Original publication available at:

https:// doi.org/ 10.1111/pai.12802

Copyright: Wiley (12 months)

http:// eu.wiley.com/WileyCDA/ 
MRS. MALIN JEDENFALK (Orcid ID : 0000-0001-5404-0428)

DR MARIA CHRISTINA JENMALM (Orcid ID : 0000-0002-2117-5366)

Article type : Original

Pregnancy modulates the allergen-induced cytokine production differently in allergic and nonallergic women

Pediatr Allergy Immunol.

Running title: Allergen-induced cytokines in pregnancy

Martina Sandberg Abelius ${ }^{1,2 *}$, Malin Jedenfalk ${ }^{1,2}{ }^{*}$, Jan Ernerudh ${ }^{3}$, Camilla Janefjord ${ }^{1,2}$, Göran Berg $^{4}$, Leif Matthiesen ${ }^{4,5}$ Maria C Jenmalm ${ }^{1,2}$

${ }^{1}$ Unit of Autoimmunity and Immune Regulation, Department of Clinical and Experimental Medicine, Linköping University, Linköping, Sweden

${ }^{2}$ Division of Paediatrics, Department of Clinical and Experimental Medicine, Linköping University, Linköping, Sweden

${ }^{3}$ Department of Clinical Immunology and Transfusion Medicine, and Department of Clinical and Experimental Medicine, Linköping University, Linköping, Sweden

${ }^{4}$ Department of Obstetrics and Gynaecology, and Department of Clinical and Experimental Medicine, Linköping University, Linköping, Sweden

This article has been accepted for publication and undergone full peer review but has not been through the copyediting, typesetting, pagination and proofreading process, which may lead to differences between this version and the Version of Record. Please cite this article as doi: 10.1111/pai.12802

This article is protected by copyright. All rights reserved. 
${ }^{5}$ Department of Obstetrics and Gynaecology, Helsingborg Hospital, Helsingborg, Sweden

*Shared first authors

Correspondence:

Malin Jedenfalk

Division of Paediatrics,

University Hospital of Linköping

SE-581 85 Linköping, Sweden

Telephone: +46-(0)10-1031331 Email: malin.jedenfalk@liu.se

\section{Abstract}

Background: The immunological environment during pregnancy may differ between allergic and non-allergic women. This study investigates the effect of maternal allergy on the allergen-induced cytokine and chemokine levels and if pregnancy modulates these immune responses differently in allergic and non-allergic women.

Methods: The birch-, cat-, phytohemagglutinin- and tetanus toxoid-induced interferon- $\gamma$ (IFN- $\gamma$ ), interleukin-4 (IL)-4, IL-5, IL-10, IL-13, the T-helper 1 (Th1)-associated chemokine CXCL10 and the Th2associated chemokine CCL17 levels were quantified in 20 women with allergic symptoms (sensitised, $n=13$ ) and 36 women without allergic symptoms (non-sensitised, $n=30$ ) at gestational weeks 10-12, $15-16,25,35$ and 2 and 12 months postpartum.

This article is protected by copyright. All rights reserved. 
Results: Birch-, but not cat-induced, IL-5, IL-13 and CCL17 levels were increased during pregnancy as compared with postpartum in the sensitised women with allergic symptoms. In contrast, cat-, but not birch-induced, IL-5 and IL-13 levels were increased during pregnancy as compared with postpartum in the non-sensitised women without allergic symptoms. Furthermore, IFN- $\gamma$ secretion was increased in the first and decreased in the second and third trimesters in response to birch and decreased in the third trimester in response to cat as compared with postpartum in the nonsensitised women without allergic symptoms. Increased allergen-induced IL-4, IL-5 and IL-13 levels were associated with allergic symptoms and sensitisation.

Conclusions: Pregnancy had a clear effect on the allergen-induced IL-5, IL-13, CCL17, IFN- $\gamma$ and CXCL10 production, with distinct enhanced Th2-responses to birch in the allergic group and to cat in the non-allergic group.

Key words: Allergy, birch, cat, chemokines, cytokines, immune regulation, T cells, pregnancy, rhinitis

Correspondence:

Malin Jedenfalk

Division of Paediatrics,

University Hospital of Linköping

SE-581 85 Linköping, Sweden

Telephone: +46-(0)10-1031331 Email: malin.jedenfalk@liu.se

This article is protected by copyright. All rights reserved. 


\section{Introduction}

The immunological similarities between allergy and pregnancy, like the Th2-deviated immune responses to allergens $(1,2)$ and at the fetal-maternal interface $(3,4)$, have raised several questions: Is maternal allergy beneficial in a reproductive perspective? Does the pregnancy magnify the Th2associated immunity in allergic women? Does a strong Th2-environment in utero influence the fetal immunity and the susceptibility of post-natal allergy development?

In fact, some studies have indicated favourable effects of maternal allergy on reproduction, including shorter waiting time to pregnancy (5), higher birth weight and length, longer gestational age (6-8) and a lower risk of pre-term birth $(9,10)$. The increased propensity of allergic mothers to mount Th2responses to allergens might, speculatively, in this perspective be considered as beneficial for pregnancy outcome. However, only a few studies have been conducted to study the effect of pregnancy on the immunity of allergic and non-allergic women (11-19). The idea of a pronounced Th2-immunity during pregnancy in allergic women is supported by the observation of increased total IgE levels in the first (20) and the third trimester (11), a lack of down-regulation of allergen-induced IL-13 production in the third trimester as compared with postpartum (12), as well as reduced IFN- $\gamma$ and IL-10 secretion in response to fetal and paternal alloantigen during and after pregnancy (13-15). The effect of pregnancy at the systemic level has been studied previously in women with the Th1associated diseases rheumatoid arthritis (RA), psoriasis and multiple sclerosis (MS). The clinical symptoms of RA, psoriasis and MS were reduced during pregnancy, while the rate of relapses increased postpartum for women with MS, indicating that the effect of pregnancy on the maternal immunity is not limited to the maternal-fetal interface (21-23).

Immune mediators, secreted systemically and locally during pregnancy, may affect the immunological environment at the fetal-maternal interface, possibly influencing the developing fetal immune system and the susceptibility of post-natal allergy development. In addition, allergens have been detected in amniotic fluid $(24,25)$. Thus, in this perspective, enhanced Th2 responses during

This article is protected by copyright. All rights reserved. 
pregnancy might be regarded as unfavourable. Accordingly, positive correlations between circulating chemokine levels during pregnancy and the offspring's chemokine levels at birth and during the first 6 years of life have been reported, with clear differences in chemokine levels during childhood between the allergic and non-allergic children (26).

In the present study, we were interested in the effect of maternal allergy on immune reactivity in terms of spontaneous, mitogen- and allergen-induced cytokine and chemokine levels, and if pregnancy modulates these immune responses differently in allergic and non-allergic women. We used a longitudinal study design to compare cytokine and chemokine responses in early-, mid- and late-gestation, and with two additional occasions postpartum. We hypothesised that maternal allergy is associated with increased Th2-associated immune responses to allergens throughout pregnancy and postpartum and that pregnancy magnifies the spontaneous, mitogen- and allergeninduced secretion of Th2-associated cytokines and chemokines in both groups, with a more dominant Th2-profile in the allergic group.

\section{Methods}

\section{Study group}

Fifty-six pregnant women were included and followed with collection of blood samples at gestational weeks (gw) 10-12, 15-16, 25, 35 and 39, and in addition at 2 and 12 months postpartum. The allergic status, i.e. symptoms of asthma, allergic rhino-conjunctivitis (ARC) and atopic dermatitis (AD), of the pregnant women were recorded by structured interviews performed by an allergy research nurse. Twenty women reported allergic symptoms, 17 women had ARC, 4 had asthma (of whom 1 also had ARC) and 2 had AD (both of them also had ARC). Thirty-six women reported no symptoms of allergic disease. Thirteen of the 20 women with allergic symptoms were sensitised and 30 of the 36 women without allergic symptoms were not sensitised, according to the Phadiatop ${ }^{\circ}$-test (circulating IgE to a

This article is protected by copyright. All rights reserved. 
panel of inhalant allergens including birch, mugwort, timothy, cat, dog, horse, Dermatophagoides pteronyssinus, farinae and Cladosporium, Phadia, Uppsala, Sweden). Hence, two different groups emerged; sensitised women with allergic symptoms $(n=13)$ and non-sensitised women without allergic symptoms $(n=30)$. The presence of an autoimmune disease was an exclusion criterion. Maternal and neonatal characteristics at the inclusion and delivery have been presented in detail elsewhere (20) and there were no statistically significant differences between the groups (Supplementary table I). With this study design with a large number of follow-ups it was not possible to have a larger number of participants, due to practical and technical reasons.

\section{Sample preparations and cell cultures}

Venous blood was drawn in heparin treated tubes (Vacuette, Greiner Labortechnik, Kremsmünster, Austria) and the peripheral blood mononuclear cells (PBMCs) were isolated and frozen as described in detail elsewhere (27). Thawing and stimulation of the PBMCs were done as previously described (28).

Briefly, 1 million viable PBMCs were stimulated with birch and cat allergen extracts, the mitogen PHA and tetanus toxoid, in the order (based on the availability of cells), doses and duration, as presented in Table 1. An unstimulated control was used to reflect the spontaneous secretion of the cytokines. The birch and cat allergen extracts were purchased from Allergologisk Laboratorium A/S, Hørsholm, Denmark, the PHA from Sigma, Stockholm, Sweden, the tetanus toxoid and the $\alpha-$ IL-4R from Calbiochem, VWR International AB, Stockholm, Sweden.

The viability of the cells was assessed with trypan blue and the mean viability of the thawed PBMCs was $90 \%$ (range: $73-100 \%$ ).

This article is protected by copyright. All rights reserved. 


\section{Quantification of IL-4, IL-5, IL-10, IL-13, IFN- $\psi$, CCL17 and CXCL10 with enzyme-linked immunosorbent assay (ELISA) and Luminex.}

IL-4 and IL-10 were quantified using commercially available ELISA kits (IL-4; Cat no. M9314, IL-10; Cat no. M9310, Peli-pair, Sanquin, Amsterdam, The Netherlands) according to the recommendations provided by the manufacturer. Determination of IL-5, IL-13, IFN- $\gamma$, and CCL17 in the birch, cat, PHA, tetanus toxoid, and control supernatants was performed using an in house Luminex assay as described in detail elsewhere (28).

The majority of the samples showed CXCL10 levels above the upper detection limit, and the samples were reanalysed diluted 1:10 and 1:100. This re-analysis of CXCL10 was done for cell supernatants from birch, cat and the unstimulated cells since the other stimulations (PHA, tetanus toxoid) showed similar levels of cytokines and chemokines in allergic and non-allergic group. The detection limits were $2 \mathrm{pg} / \mathrm{ml}$ for CCL17, $4 \mathrm{pg} / \mathrm{ml}$ for IL-4, $5 \mathrm{pg} / \mathrm{ml}$ for IL-10, $14 \mathrm{pg} / \mathrm{ml}$ for IL-5 and IFN- $\mathrm{x}, 41 \mathrm{pg} / \mathrm{ml}$ for IL-13 and $6 \mathrm{pg} / \mathrm{ml}$ for CXCL10.

\section{Statistics and data handling}

The detection limits were established as the lowest point of the standard curve where the signal (optical density for ELISA and median fluorescence intensity for Luminex) was clearly increased as compared to the blank sample. Samples with signals below this limit were regarded as undetectable and these samples were given half the value of the detection limit. The unstimulated levels were subtracted from the stimulated levels, to achieve induced cytokine/chemokine levels. If the difference became smaller than half the value of the detection limit, they were given half the value of the detection limit. Non-parametric tests, corrected for ties, were used (IBM SPSS Statistics 21.0, SPSS Inc., Chicago, IL, USA) and $\mathrm{p}<0.05$ was considered as significant. The Wilcoxon signed rank test was used for comparisons between paired samples and Mann-Whitney $U$-test for unpaired groups.

This article is protected by copyright. All rights reserved. 
The $X^{2}$ test was used for categorical variables, and the Fisher's exact test was used when the expected frequency for any cell was less than 5.

Ethics

All women gave their informed consent to participate in the study. The Regional Ethics Committee for Human Research in Linköping approved the study.

\section{Results}

\section{Effect of maternal allergy on the spontaneous and induced cytokine and chemokine levels}

The allergen-induced cytokine responses were clearly influenced by maternal allergy (sensitised women with allergic symptoms), with higher levels of birch-induced IL-4 at gw 25 , IL-5 at gw 10-12, 25 and 35, and IL-13 at gw 35 in the sensitised women with allergic symptoms as compared with the non-sensitised women without allergic symptoms ( $p=0.04-0.01$, Supplementary table II). Similarly, sensitised women with allergic symptoms had higher cat-induced IL-4 secretion at gw 15, 25, 35 and 2 and 12 months postpartum, IL-5 at gw 10-12, 15-16 and 2 months postpartum and IL-13 at gw 1516 than the non-sensitised women without allergic symptoms $(p=0.046-0.001$, Supplementary table III). The allergen-induced IL-10, IFN- - , CCL17 and CXCL10 levels were similar in the two groups at all occasions (Supplementary table II and III for birch and cat, respectively). The spontaneous (unstimulated control), PHA- and tetanus toxoid-induced cytokine and chemokine levels did not differ between the two groups at any occasion, with one exception; the unstimulated secretion of IL10 was increased at gw 35 in the sensitised women with allergic symptoms compared with the nonsensitised women without allergic symptoms $(p=0.03)$.

This article is protected by copyright. All rights reserved. 


\section{Effect of pregnancy on the spontaneous, PHA- and tetanus toxoid-induced cytokine and chemokine responses}

In contrast to the allergen-induced cytokine and chemokine secretion, which was affected by maternal allergy, the spontaneous (unstimulated control), PHA- and tetanus toxoid-induced cytokine and chemokine levels were not significantly altered by maternal allergy (sensitisation combined with allergic symptoms). Therefore, these data are presented collectively for the 56 women with and without allergic symptoms, as a characterisation of a normal pregnancy (Figure 1). The unstimulated IL-10 secretion was lower at gw $10-12$ and $15-16$ as compared with 2 and 12 months postpartum $(p=0.04-0.005)$, and the CCL17 secretion was lower at gw 25 and 35 than 12 months postpartum ( $p=0.04$ and $p=0.01$, respectively). The unstimulated IL-10 secretion was also analysed separately, in the sensitised women with allergic symptoms and the non-sensitised women without allergic symptoms, as the IL-10 levels differed between the groups at one occasion. No differences in the unstimulated IL-10 secretion were detected during pregnancy and postpartum, when the allergic status of the mother was taken into account. The unstimulated IL-5, IL-13 and IFN- $\gamma$ secretion and the tetanus toxoid-induced responses (all analytes) were not modified during pregnancy. The PHAinduced IL-10 and IFN- $\gamma$ levels were decreased whereas IL-5, IL-13 and CCL17 levels were increased during pregnancy as compared with postpartum (Fig 1).

\section{Birch- and cat-induced cytokine and chemokine responses are modulated during pregnancy in} allergic and non-allergic women

The allergen-induced levels of IL-5, IL-13, CCL17, CXCL10 and IFN- - , but not IL-4 and IL-10, were modulated during pregnancy, with distinct differences between the groups depending on the specific allergen stimulation (Fig 2-3). In the sensitised women with allergic symptoms, birch-induced IL-5, IL-13 and CCL17 levels were increased at various time points during pregnancy as compared with 2 months postpartum (Fig $2 \mathrm{~A}-\mathrm{C}$ ), while no alterations in the IFN- - levels were observed during This article is protected by copyright. All rights reserved. 
pregnancy and after delivery. However, the birch-induced CXCL10 secretion was increased in the gw 25 compared with 12 months postpartum in the sensitised women with allergic symptoms. The birch-induced levels of IL-5, IL-13 and CCL17 were similar during pregnancy and postpartum in the non-sensitised women without allergic symptoms, while the IFN- $\gamma$ responses to birch were increased at gw 10-12 as compared with 12 months postpartum and decreased at gw 15-16, 25, 35 as compared with 2 months postpartum (Fig 3). The birch-induced CXCL10 levels were decreased in the second trimester compared with postpartum in the non-sensitised women (Fig 3).

The cat-induced cytokine and chemokine levels were not modified during pregnancy in the sensitised women with allergic symptoms. In contrast, the non-sensitised women without allergic symptoms had increased IL-5 responses to cat at gw 25 and 35 as compared with 2 months postpartum ( $p=0.03$ and $p=0.047$, respectively), higher cat-induced IL-13 levels at gw 10-12 than 12 months postpartum $(p=0.04)$ and lower IFN- - levels at gw 35 than 2 months after delivery $(p=0.001)$.

\section{Discussion}

A pregnancy in which the mother and the fetus peacefully coexist is a unique immunological situation (29). Cytokines and chemokines are key mediators for the function of the immune system, playing important roles for maintenance of pregnancy and the allergic inflammation. The aberrant cytokine secretion in allergic individuals, i.e. increased secretion of allergen-induced Th2-associated cytokines, might influence the immune regulation during pregnancy with magnified Th2-responses as a result. Accordingly, we found an enhanced secretion of Th2-associated IL-5, IL-13 and CCL17 levels during pregnancy to the seasonal allergen birch, but not to the perennial allergen cat in the sensitised women with allergic symptoms, as well as increased IL-5 and IL-13 levels during pregnancy to cat, but not to birch in the non-sensitised women without allergic symptoms. Thus, our data indicate that certain allergen-specific responses are magnified during pregnancy in both groups. Cat-

This article is protected by copyright. All rights reserved. 
ownership was recorded in the questionnaires. Eight non-sensitised women without allergic symptoms owned a cat but none of the sensitised women with allergic symptoms did, probably indicating a more persistent and a higher exposure to cat allergen during pregnancy in the nonallergic group. Others have observed that chronic cat exposure can modulate the immune response (30). Even though maternal allergy was not associated with increased cat-induced IL-5 and IL-13 levels during pregnancy as compared with postpartum, it is important to note that the absolute levels of these Th2-associated cytokines were higher in sensitised women with allergic symptoms than non-sensitised women without allergic symptoms in early gestation. This strong Th2-associated environment during pregnancy, particularly obvious in the allergic women, might influence fetal immune development.

In addition to Th2 responses, also Th1-associated mediators were modified during pregnancy. In the non-allergic group the IFN- $\gamma$ secretion increased in the first and decreased in the second and third trimesters of pregnancy as compared with postpartum. Similarly, IFN- $\gamma$ secretion in response to cat was down-regulated in the third trimester. In line with this, the birch induced CXCL10 levels decreased in the second trimester in the non-allergic women but surprisingly increased in the second trimester compared with postpartum in the allergic women. No alterations were seen for the cat-induced CXCL10-secretion. IFN- $-\gamma$ might be necessary during implantation (31), indicating that Th1-like immune responses might be important in early pregnancy. Decreased IFN- $\gamma$ responses to cat- and house dust mite extracts during pregnancy have been reported, with similar patterns in allergic and non-allergic women (12). In contrast, the present study did not reveal alterations in the allergen-induced IFN- $\gamma$ secretion in the allergic group. We have previously reported a decreased capacity of the sensitised women with allergic symptoms in this cohort to produce IFN- $\gamma$ and IL-10 to paternal antigens and pooled unrelated antigens during pregnancy (13). Thus, certain antigens may modulate Th1- and Th2-responses during pregnancy whereas other antigens do not. Various

This article is protected by copyright. All rights reserved. 
environmental factors can influence the study results, as well as intermittent intake of anti-allergic drugs. The possibility of type II errors cannot be excluded. The allergen-induced levels of the regulatory/anti-inflammatory cytokine IL-10 were not modulated during pregnancy in any of the groups, and the spontaneous and PHA-induced IL-10 secretion were actually decreased in early gestation. This was surprising, but others have also failed to reveal increased allergen-induced and circulating IL-10 levels systemically during pregnancy as compared with postpartum (12). Furthermore, the IL-10 levels in plasma were lower in mid-gestation as compared to non-pregnant controls (32) and PHA-stimulated PBMC:s produced less IL-10 in the third trimester of pregnancy than 2 years postpartum (11). As PHA predominantly activates T lymphocytes, one could speculate that lipopolysaccharide-induced activation of IL-10 secreting monocytes might reveal a discrepant pattern for IL-10 secretion during and after pregnancy. It would have been interesting to study cytokine secretion from T and B cell populations separately as others have described different IL10 production by $T$ and $B$ cells during pregnancy in allergic and non-allergic women(16). The spontaneous CCL17 secretion was also decreased during pregnancy, which is in line with our previous finding of decreased circulating CCL17 levels during pregnancy as compared with postpartum. The PHA-induced IL-5, IL-13 and CCL17 levels were increased, and the IFN- $\gamma$ levels were decreased during pregnancy as compared with postpartum, supporting the traditional point of view of pregnancy as a Th2-dominant situation. Others also observed lower PHA-induced IFN- $\gamma$ responses from PBMC:s in pregnant asthmatic women compared with healthy non-pregnant women(19).

In conclusion, birch- and cat-induced cytokine and chemokine secretion were modified during pregnancy, with enhanced Th2-associated responses during pregnancy in allergic and non-allergic women, decreased Th1-associated responses during pregnancy in non-allergic women as compared with postpartum, indicating that pregnancy influences the regulation of antigen-specific immune responses, with magnified Th2-responses as a result. Furthermore, the allergen-induced IL-4, IL-5

This article is protected by copyright. All rights reserved. 
and IL-13 levels were increased in the allergic as compared with the non-allergic women, indicating that the observed Th2-polarisation to allergens during pregnancy is possibly pronounced in the allergic group. The pronounced Th2-profile during pregnancy in the allergic women might influence fetal immune development, possibly contributing to the increased risk of allergy development in offspring's of allergic mothers.

\section{Acknowledgement}

We would like to thank the women who participated in the study, the midwives at the maternity health care clinic and research nurse Lena Lindell for excellent assistance. We also thank Anne-Marie Fornander for outstanding support and performance of laboratory analyses.

The Swedish Research Council (project 73X-15335-01A and 74X-20146-01-2), the National Swedish Association against Allergic Diseases, the National Heart and Lung Association, the Vårdal Foundation - for Health Care Sciences and Allergy Research, Olle Engkvist Foundation, the Cancer and Allergy Association, Samariten Foundation, Queen Silvia research foundation, Ellen, Walter and Lennart Hesselmans foundation and the County Council of Östergötland are acknowledged for financial support.

\section{Figure legends}

Figure 1. The PHA-induced (A) IFN- $\gamma$, (B) IL-10, (C) IL-5, (D) IL-13 and (E) CCL17 levels were modified by the pregnancy in 56 women with a normal pregnancy, irrespectively of maternal allergy. The figure shows median (solid line) and IQR, 1st and 3rd quartile values, (broken lines). ${ }^{*}=p<0.05,{ }^{* *}=$ $p<0.01, * * *=p<0.001$, Wilcoxon's signed rank test.

This article is protected by copyright. All rights reserved. 
Figure 2. Birch-induced (A) IL-5, (B) IL-13 and (C) CCL17 levels in sensitised women with allergic symptoms and non-sensitised women without allergic symptoms during pregnancy and after delivery. The number of positive responders and the total number of samples are indicated below the $x$-axis.

$*=p<0.05,{ }^{* *}=p<0.01$, Wilcoxon's signed rank test. The box indicates the 25 th, 50 th and 75 th percentiles and the whiskers indicate minimum and maximum values.

Figure 3. Birch-induced (A) IFN- $\gamma$ and (B) CXCL10 secretion in sensitised women with allergic symptoms and non-sensitised women without allergic symptoms during pregnancy and after delivery. The number of positive responders and the total number of samples are indicated below the $x$-axis.

${ }^{*}=p<0.05,{ }^{* *}=p<0.01$, Wilcoxon's signed rank test. The box indicates the 25 th, 50 th and 75 th percentiles and the whiskers indicate minimum and maximum values.

This article is protected by copyright. All rights reserved. 
Table 1. Protocol used for in vitro stimulation

\begin{tabular}{|c|c|c|c|}
\hline Priority & Stimulation & Time (days) & Analytes \\
\hline 1 & $\begin{array}{l}\text { Unstimulated control } \\
\text { (medium) }\end{array}$ & 6 & IL-5, IL-13, IFN- $\gamma$, CCL17, CXCL10 \\
\hline 2 & Birch (10 kSU/ml) & 6 & IL-5, IL-13, IFN- $\gamma$, CCL17, CXCL10 \\
\hline 3 & PHA $(2 \mu \mathrm{g} / \mathrm{ml})$ & 1 & IL-10, IL-5, IL-13, IFN- $\gamma$, CCL17 \\
\hline 4 & Cat $(10 \mathrm{kSU} / \mathrm{ml})$ & 6 & IL-5, IL-13, IFN- $\gamma$, CCL17, CXCL10 \\
\hline 5 & $\begin{array}{l}\text { Birch (10 kSU/ml) } \\
\alpha-I L-4 R(2 \mu g / m l)\end{array}$ & 6 & IL-4 \\
\hline 6 & $\begin{array}{l}\text { Cat (10 kSU/ml) } \\
\alpha-I L-4 R(2 \mu g / m l)\end{array}$ & 6 & IL-4 \\
\hline 7 & Control (medium) & 1 & IL-10 \\
\hline 8 & Birch (10 kSU/ml) & 1 & IL-10 \\
\hline 9 & Cat (10 kSU/ml) & 1 & IL-10 \\
\hline 10 & Tetanus toxoid $(100 \mathrm{ng} / \mathrm{ml})$ & 6 & IL-5, IL-13, IFN-,- CCL17 \\
\hline 11 & Tetanus toxoid $(100 \mathrm{ng} / \mathrm{ml})$ & 1 & IL-10 \\
\hline 12 & $\begin{array}{l}\text { Tetanus toxoid }(100 \mathrm{ng} / \mathrm{ml}) \\
\boldsymbol{\alpha - I L - 4 R ~}(2 \mu \mathrm{g} / \mathrm{ml})\end{array}$ & 6 & IL-4 \\
\hline
\end{tabular}

Abbreviations used: PHA = phytohemagglutinin, $\alpha-I L-4 R=$ anti-IL-4 receptor.

This article is protected by copyright. All rights reserved. 


\section{References}

1 Jenmalm MC, Van Snick J, Cormont F, Salman B. Allergen-induced Th1 and Th2 cytokine secretion in relation to specific allergen sensitization and atopic symptoms in children. Clin Exp Allergy. 2001; 31: 1528-35.

2 Mazzarella G, Bianco A, Catena E, De Palma R, Abbate GF. Th1/Th2 lymphocyte polarization in asthma. Allergy. 2000; 55 Suppl 61: 6-9.

3 Wegmann TG, Lin H, Guilbert L, Mosmann TR. Bidirectional cytokine interactions in the maternal-fetal relationship: is successful pregnancy a TH2 phenomenon? Immunol Today. 1993; 14: 353-6.

$4 \quad$ McFadden JP, Thyssen JP, Basketter DA, Puangpet P, Kimber I. T helper cell 2 immune skewing in pregnancy/early life: chemical exposure and the development of atopic disease and allergy. Br J Dermatol. 2015; 172: 584-91.

5 Westergaard T, Begtrup K, Rostgaard K, Krause TG, Benn CS, Melbye M. Reproductive history and allergic rhinitis among 31145 Danish women. Clin Exp Allergy. 2003; 33: 301-5.

6 Somoskovi A, Bartfai Z, Tamasi L, Kocsis J, Puho E, Czeizel AE. Population-based casecontrol study of allergic rhinitis during pregnancy for birth outcomes. Eur J Obstet Gynecol Reprod Biol. 2007; 131: 21-7.

$7 \quad$ Schaub B, Liu J, Hoppler S, et al. Impairment of T-regulatory cells in cord blood of atopic mothers. J Allergy Clin Immunol. 2008; 121: 1491-9, 99 e1-13.

8 Tedner SG, Ortqvist AK, Almqvist C. Fetal growth and risk of childhood asthma and allergic disease. Clin Exp Allergy. 2012; 42: 1430-47.

9 Savilahti E, Siltanen M, Pekkanen J, Kajosaari M. Mothers of very low birth weight infants have less atopy than mothers of full-term infants. Clin Exp Allergy. 2004; 34: 1851-4.

10 Tronnes H, Wilcox AJ, Markestad T, Tollanes MC, Lie RT, Moster D. Associations of maternal atopic diseases with adverse pregnancy outcomes: a national cohort study. Paediatr Perinat Epidemiol. 2014; 28: 489-97.

11 Amoudruz P, Minang JT, Sundstrom Y, et al. Pregnancy, but not the allergic status, influences spontaneous and induced interleukin-1beta (IL-1beta), IL-6, IL-10 and IL-12 responses. Immunology. 2006; 119: 18-26.

12 Breckler LA, Hale J, Jung W, et al. Modulation of in vivo and in vitro cytokine production over the course of pregnancy in allergic and non-allergic mothers. Pediatr Allergy Immunol. 2010; 21: 14-21.

13

Persson M, Ekerfelt C, Ernerudh J, et al. Reduced IFN-gamma and IL-10 responses to paternal antigens during and after pregnancy in allergic women. J Reprod Immunol. 2012; 95: 50-8.

This article is protected by copyright. All rights reserved. 

show reduced T helper type 1 alloresponses to fetal human leucocyte antigen mismatch during pregnancy. Clin Exp Immunol. 2010; 159: 65-72.

15

Breckler LA, Hale J, Taylor A, Dunstan JA, Thornton CA, Prescott SL. Pregnancy IFNgamma responses to foetal alloantigens are altered by maternal allergy and gravidity status. Allergy. 2008; 63: 1473-80.

16

Martins C, Lima J, Nunes G, Borrego LM. Regulatory T and B Cells in Asthmatic

Women: Variations From Pregnancy to Postpartum. J Investig Allergol Clin Immunol. 2017; 27: 46-57.

17

Toldi G, Molvarec A, Stenczer B, et al. Peripheral T(h)1/T(h)2/T(h)17/regulatory T-cell balance in asthmatic pregnancy. Int Immunol. 2011; 23: 669-77.

18

Martins C, Lima J, Nunes G, Borrego LM. Pregnancy alters the circulating B cell compartment in atopic asthmatic women, and transitional $B$ cells are positively associated with the development of allergy manifestations in their progeny. Am J Reprod Immunol. 2016; 76: 465-74.

19 Vanders RL, Gibson PG, Wark PA, Murphy VE. Alterations in inflammatory, antiviral and regulatory cytokine responses in peripheral blood mononuclear cells from pregnant women with asthma. Respirology. 2013; 18: 827-33.

20 Sandberg M, Frykman A, Jonsson Y, et al. Total and allergen-specific IgE levels during and after pregnancy in relation to maternal allergy. J Reprod Immunol. 2009; 81: 82-8.

21 Ceovic R, Mance M, Bukvic Mokos Z, Svetec M, Kostovic K, Stulhofer Buzina D. Psoriasis: female skin changes in various hormonal stages throughout life--puberty, pregnancy, and menopause. Biomed Res Int. 2013; 2013: 571912.

22 de Man YA, Dolhain RJ, van de Geijn FE, Willemsen SP, Hazes JM. Disease activity of rheumatoid arthritis during pregnancy: results from a nationwide prospective study. Arthritis Rheum. 2008; 59: 1241-8.

23 Confavreux C, Hutchinson M, Hours MM, Cortinovis-Tourniaire P, Moreau T. Rate of pregnancy-related relapse in multiple sclerosis. Pregnancy in Multiple Sclerosis Group. N Engl J Med. 1998; 339: 285-91.

24 Holloway JA, Warner JO, Vance GH, Diaper ND, Warner JA, Jones CA. Detection of house-dust-mite allergen in amniotic fluid and umbilical-cord blood. Lancet. 2000; 356: 1900-2.

25 Pastor-Vargas C, Maroto AS, Diaz-Perales A, et al. Detection of major food allergens in amniotic fluid: initial allergenic encounter during pregnancy. Pediatr Allergy Immunol. 2016; 27: 71620. allergic children and influenced by maternal immunity during pregnancy. Pediatr Allergy Immunol. 2014; 25: 387-93.

This article is protected by copyright. All rights reserved. 

IFN-gamma- and IL-4-secreting cells during pregnancy in allergic and non-allergic women. $J$ Reprod Immunol. 2008.

28

Forsberg A, Abrahamsson TR, Bjorksten B, Jenmalm MC. Pre- and post-natal Lactobacillus reuteri supplementation decreases allergen responsiveness in infancy. Clin Exp Allergy. 2013; 43: 434-42.

29 PrabhuDas M, Bonney E, Caron K, et al. Immune mechanisms at the maternal-fetal interface: perspectives and challenges. Nat Immunol. 2015; 16: 328-34.

30

Renand A, Archila LD, McGinty J, et al. Chronic cat allergen exposure induces a TH2 cell-dependent IgG4 response related to low sensitization. J Allergy Clin Immunol. 2015; 136: 162735 e1-13.

31

Ashkar AA, Di Santo JP, Croy BA. Interferon gamma contributes to initiation of uterine vascular modification, decidual integrity, and uterine natural killer cell maturation during normal murine pregnancy. J Exp Med. 2000; 192: 259-70.

32

Power LL, Popplewell EJ, Holloway JA, Diaper ND, Warner JO, Jones CA.

Immunoregulatory molecules during pregnancy and at birth. J Reprod Immunol. 2002; 56: 19-28.

Fig 1
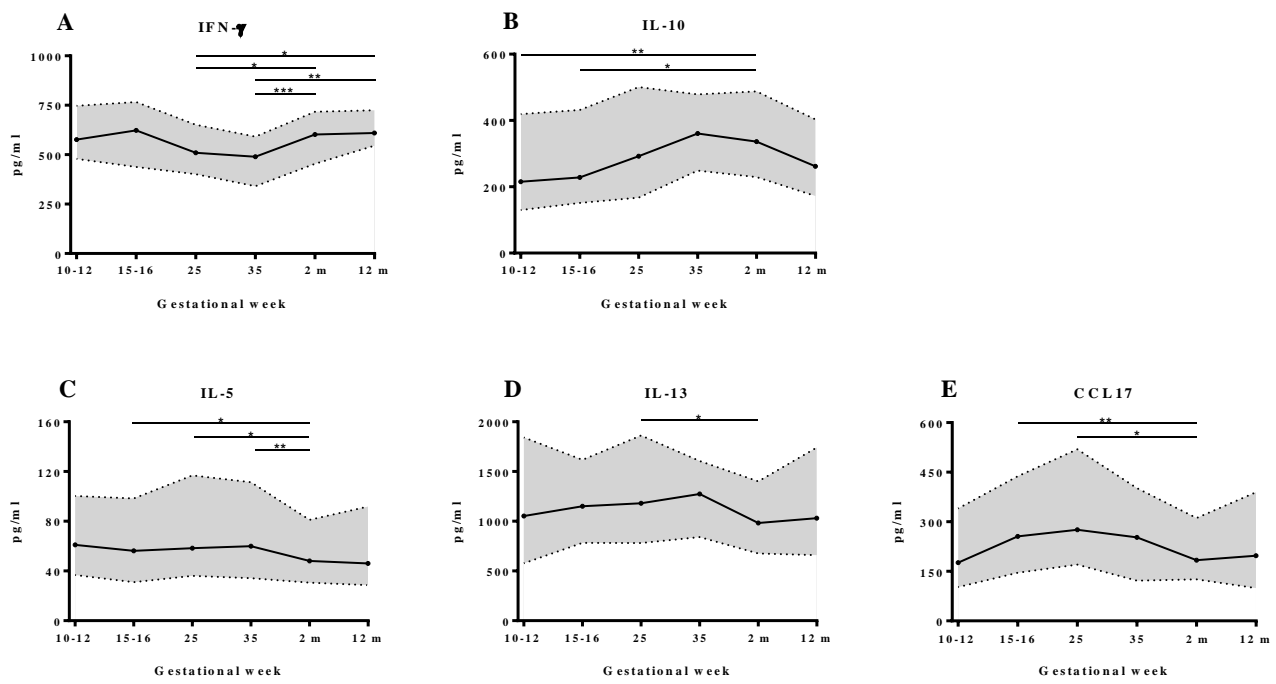

This article is protected by copyright. All rights reserved. 
Fig 2

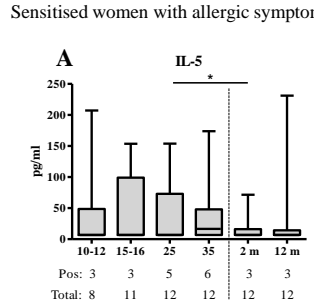

Non-sensitised women without allergic symptoms
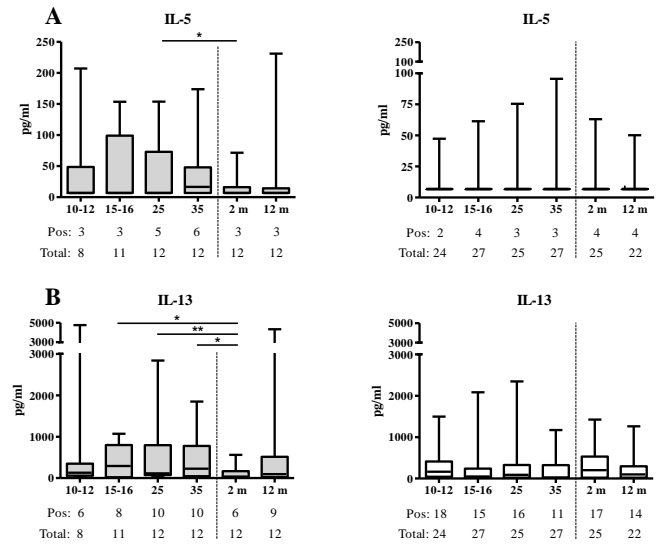

IL-13
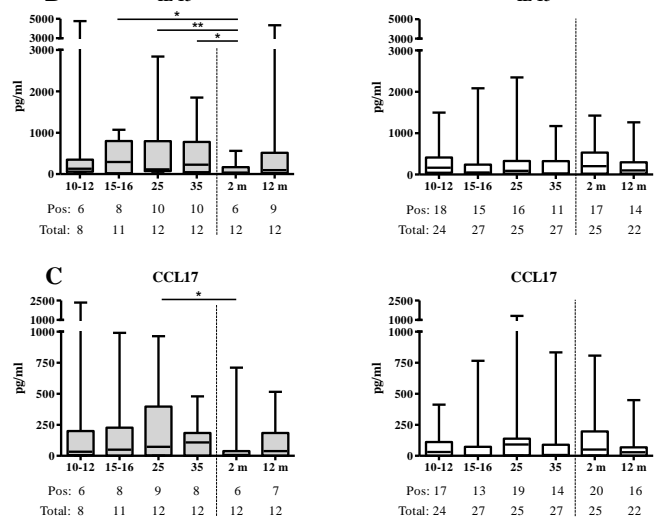

Fig 3

Sensitised women with allergic symptoms

Non-sensitised women without allergic symptoms
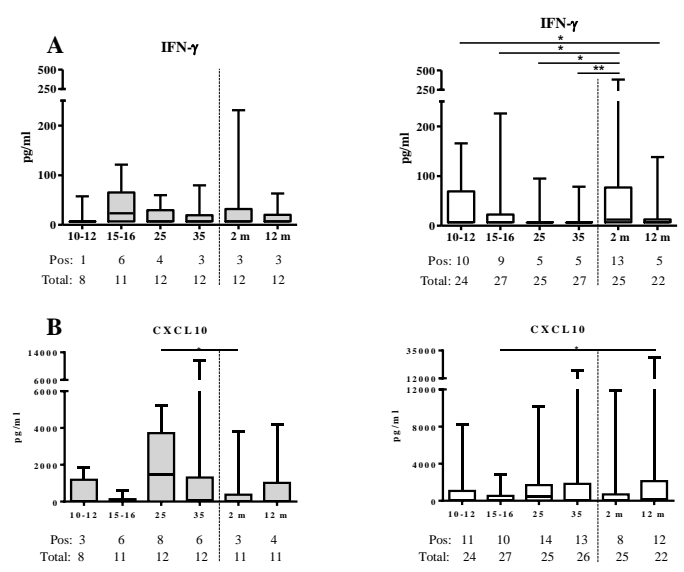

This article is protected by copyright. All rights reserved. 
Supplementary Table I. Maternal and neonatal characteristics for the 56 women and children participating in the study

\begin{tabular}{|c|c|c|c|c|}
\hline $\begin{array}{l}\text { Maternal characteristics } \\
\text { median (range) }\end{array}$ & $\begin{array}{l}\text { Women with allergic } \\
\text { symptoms } \\
(n=20)\end{array}$ & $\begin{array}{l}\text { Sensitised women with } \\
\text { allergic symptoms } \\
\qquad(n=13)\end{array}$ & $\begin{array}{l}\text { Women without allergic } \\
\text { symptoms } \\
(n=36)\end{array}$ & $\begin{array}{l}\text { Non-sensitised women } \\
\text { without allergic symptoms } \\
(n=30)\end{array}$ \\
\hline Maternal age at delivery (yr) & $31(24-38)$ & $31(24-38)$ & $31(22-40)$ & $31(22-40)$ \\
\hline Body Mass Index at gwk 10 & $23(18-32)$ & $23(21-32)$ & $24(19-34)$ & $23(19-29)$ \\
\hline Gestational age (wk) & $40(38-42)$ & $40(39-42)$ & $40(34-42)$ & $40(34-42)$ \\
\hline \multicolumn{5}{|l|}{$\begin{array}{l}\text { Maternal characteristics } \\
\text { number }\end{array}$} \\
\hline $\begin{array}{l}\text { Previous successful } \\
\text { pregnancies }\end{array}$ & $\begin{array}{l}\text { primiparous } n=10 \\
\text { parous } n=10\end{array}$ & $\begin{array}{l}\text { primiparous } n=8 \\
\text { parous } n=5\end{array}$ & $\begin{array}{l}\text { primiparous } n=14 \\
\text { parous } n=22\end{array}$ & $\begin{array}{l}\text { primiparous } n=13 \\
\text { parous } n=17\end{array}$ \\
\hline Caesarean section & $n=3$ & $n=3$ & $n=7$ & $n=7$ \\
\hline Smoking during pregnancy & $\mathrm{n}=1$ & $\mathrm{n}=1$ & $n=6$ & $n=5$ \\
\hline \multicolumn{5}{|l|}{$\begin{array}{l}\text { Neonatal characteristics } \\
\text { median (range) }\end{array}$} \\
\hline Birth length $(\mathrm{cm})$ & $51.5(48-54)$ & $51(49-54)$ & $51(45-54)$ & $50.5(45-54)$ \\
\hline Birth weight (g) & $3815(3000-4490)$ & $3800(3000-4490)$ & $3650(2580-4210)$ & $3610(2580-4210)$ \\
\hline \multicolumn{5}{|l|}{$\begin{array}{l}\text { Neonatal characteristics } \\
\text { number }\end{array}$} \\
\hline Sex & boys $n=13$, girls $n=7$ & boys $n=7$, girls $n=6$ & boys $n=19$, girls $n=17$ & boys $n=17$, girls $n=13$ \\
\hline
\end{tabular}

yr=years, wk=weeks, gwk=gestational week. Fifty-six pregnant women were included in the study, 20 women with allergic symptoms (second column in the table) and 36 women without allergic symptoms (forth column in the table). Thirteen of the 20 women who reported allergic symptoms were also sensitised (third column in the table). Thirty of the 36 women without allergic symptoms were non-sensitised. There were no significant differences between the groups regarding the maternal and neonatal characteristics shown in the table. Data regarding Body Mass Index was missing for 1 nonsensitised woman without allergic symptoms and regarding smoking habits during pregnancy for 1 non-sensitised woman without allergic symptoms. The $X^{2}$ test was used for categorical variables, and the Fisher's exact test was used when the expected frequency for any cell was less than 5 . Mann-Whitney $U$ test was used for continuous variables. 
Supplementary Table II. Birch induced cytokine and chemokine responses in sensitised women with allergic symptoms and non-sensitised women without allergic symptoms $(\mathrm{pg} / \mathrm{ml})$. Median, IQR $\left(1^{\text {st }}\right.$ and $3^{\text {rd }}$ quartile values) are indicated.

\begin{tabular}{|c|c|c|c|c|c|c|c|c|c|c|c|c|c|c|c|c|c|c|}
\hline \multirow[t]{2}{*}{ Birch } & \multicolumn{3}{|c|}{$\begin{array}{l}\text { Gestational week } \\
10-12\end{array}$} & \multicolumn{3}{|c|}{$\begin{array}{l}\text { Gestational } \\
\text { week } 15\end{array}$} & \multicolumn{3}{|c|}{$\begin{array}{l}\text { Gestational week } \\
25\end{array}$} & \multicolumn{3}{|c|}{$\begin{array}{l}\text { Gestational } \\
\text { week } 35\end{array}$} & \multicolumn{3}{|c|}{$\begin{array}{l}2 \text { months } \\
\text { post partum }\end{array}$} & \multicolumn{3}{|c|}{$\begin{array}{l}12 \text { months } \\
\text { post partum }\end{array}$} \\
\hline & $\begin{array}{l}\text { Sens + } \\
\text { Allergic } \\
\text { symp }\end{array}$ & $\begin{array}{l}\text { Non-sens + } \\
\text { No allergic } \\
\text { symp }\end{array}$ & $\mathbf{p}$ & $\begin{array}{l}\text { Sens + } \\
\text { Allergic } \\
\text { symp }\end{array}$ & $\begin{array}{l}\text { Non-sens + } \\
\text { No allergic } \\
\text { symp }\end{array}$ & $\mathbf{p}$ & $\begin{array}{l}\text { Sens + } \\
\text { Allergic } \\
\text { symp }\end{array}$ & $\begin{array}{l}\text { Non-sens + } \\
\text { No allergic } \\
\text { symp }\end{array}$ & $\mathbf{p}$ & $\begin{array}{l}\text { Sens + } \\
\text { Allergic } \\
\text { symp }\end{array}$ & $\begin{array}{l}\text { Non-sens + } \\
\text { No allergic } \\
\text { symp }\end{array}$ & $\mathbf{p}$ & $\begin{array}{l}\text { Sens + } \\
\text { Allergic } \\
\text { symp }\end{array}$ & $\begin{array}{l}\text { Non-sens + } \\
\text { No allergic } \\
\text { symp }\end{array}$ & $\mathbf{p}$ & $\begin{array}{l}\text { Sens + } \\
\text { Allergic } \\
\text { symp }\end{array}$ & $\begin{array}{l}\text { Non-sens + } \\
\text { No allergic } \\
\text { symp }\end{array}$ & $\mathbf{p}$ \\
\hline IL-4 & $\begin{array}{l}2.0 \\
(2.0-2.0)\end{array}$ & $\begin{array}{l}2.0 \\
(2.0-2.0)\end{array}$ & 1.0 & $\begin{array}{l}2.0 \\
(2.0-5.1)\end{array}$ & $\begin{array}{l}2.0 \\
(2.0-2.0)\end{array}$ & 0.2 & $\begin{array}{l}2.0 \\
* 44.4 \% \text { pos } \\
(2.0-5.5)\end{array}$ & $\begin{array}{l}2.0 \\
* 8.7 \% \text { pos } \\
(2.0-2.0)\end{array}$ & 0.03 & $\begin{array}{l}2.0 \\
(2.0-10.8)\end{array}$ & $\begin{array}{l}2.0 \\
(2.0-2.0)\end{array}$ & 0.07 & $\begin{array}{l}2.0 \\
(2.0-3.5)\end{array}$ & $\begin{array}{l}2.0 \\
(2.0-2.0)\end{array}$ & 0.8 & $\begin{array}{l}2.0 \\
(2.0-2.0)\end{array}$ & $\begin{array}{l}2.0 \\
(2.0-2.0)\end{array}$ & 0.1 \\
\hline IL-5 & $\begin{array}{l}6.9 \\
* 37.5 \% \text { pos } \\
(6.9-56.7)\end{array}$ & $\begin{array}{l}6.9 \\
* 8.3 \% \text { pos } \\
(6.9-6.9)\end{array}$ & 0.04 & $\begin{array}{l}6.9 \\
(6.9-99.1)\end{array}$ & $\begin{array}{l}6.9 \\
(6.9-6.9)\end{array}$ & 0.2 & $\begin{array}{l}6.9 \\
* 41.7 \% \text { pos } \\
(6.9-74.4)\end{array}$ & $\begin{array}{l}6.9 \\
{ }^{*} 12 \% \text { pos } \\
(6.9-6.9)\end{array}$ & 0.02 & $\begin{array}{l}16.5 \\
* 50 \% \text { pos } \\
(6.9-51.4)\end{array}$ & $\begin{array}{l}6.9 \\
* 11.1 \% \text { pos } \\
(6.9-6.9)\end{array}$ & 0.01 & $\begin{array}{l}6.9 \\
(6.9-20.9)\end{array}$ & $\begin{array}{l}6.9 \\
(6.9-6.9)\end{array}$ & 0.5 & $\begin{array}{l}6.9 \\
(6.9-18.0)\end{array}$ & $\begin{array}{l}6.9 \\
(6.9-6.9)\end{array}$ & 0.5 \\
\hline IL-10 & $\begin{array}{l}2.4 \\
(2.4-2.4)\end{array}$ & $\begin{array}{l}2.5 \\
(2.4-29.1)\end{array}$ & 0.08 & $\begin{array}{l}2.4 \\
(2.4-2.4)\end{array}$ & $\begin{array}{l}2.4 \\
(2.4-6.5)\end{array}$ & 0.1 & $\begin{array}{l}2.4 \\
(2.4-22.0)\end{array}$ & $\begin{array}{l}2.4 \\
(2.4-15.7)\end{array}$ & 0.6 & $\begin{array}{l}6.1 \\
(2.4-18.9)\end{array}$ & $\begin{array}{l}2.6 \\
(2.4-20.8)\end{array}$ & 1.0 & $\begin{array}{l}7.3 \\
(2.4-66.9)\end{array}$ & $\begin{array}{l}6.2 \\
(2.4-52.5)\end{array}$ & 1.0 & $\begin{array}{l}2.4 \\
(2.4-5.8)\end{array}$ & $\begin{array}{l}4.7 \\
(2.4-64.8)\end{array}$ & 0.2 \\
\hline IL-13 & $\begin{array}{l}129.2 \\
(39.2-402.7)\end{array}$ & $\begin{array}{l}164.5 \\
(31.4-420.9)\end{array}$ & 0.9 & $\begin{array}{l}291.5 \\
(20.6-798.2)\end{array}$ & $\begin{array}{l}47.7 \\
(20.6-239.2)\end{array}$ & 0.08 & $\begin{array}{l}114.2 \\
(69.7-907.3)\end{array}$ & $\begin{array}{l}90.2 \\
(20.6-327.1)\end{array}$ & 0.2 & $\begin{array}{l}227.0 \\
(36.2-815.4)\end{array}$ & $\begin{array}{l}20.6 \\
(20.6-323.9)\end{array}$ & 0.02 & $\begin{array}{l}34.6 \\
(20.6-176.6)\end{array}$ & $\begin{array}{l}201.1 \\
(20.6-529.3)\end{array}$ & 0.08 & $\begin{array}{l}94.5 \\
(21.9-682.0)\end{array}$ & $\begin{array}{l}99.8 \\
(20.6-287.2)\end{array}$ & 0.7 \\
\hline IFNy & $\begin{array}{l}6.9 \\
(6.9-6.9)\end{array}$ & $\begin{array}{l}6.9 \\
(6.9-69.6)\end{array}$ & 0.1 & $\begin{array}{l}23.4 \\
(6.9-65.3)\end{array}$ & $\begin{array}{l}6.9 \\
(6.9-22.5)\end{array}$ & 0.1 & $\begin{array}{l}6.9 \\
(6.9-29.9)\end{array}$ & $\begin{array}{l}6.9 \\
(6.9-6.9)\end{array}$ & 0.4 & $\begin{array}{l}6.9 \\
(6.9-25.6)\end{array}$ & $\begin{array}{l}6.9 \\
(6.9-6.9)\end{array}$ & 0.7 & $\begin{array}{l}6.9 \\
(6.9-44.3)\end{array}$ & $\begin{array}{l}12.3 \\
(6.9-76.9)\end{array}$ & 0.2 & $\begin{array}{l}6.9 \\
(6.9-26.7)\end{array}$ & $\begin{array}{l}6.9 \\
(6.9-9.7)\end{array}$ & 0.8 \\
\hline CCL17 & $\begin{array}{l}32.3 \\
(3.1-268.9)\end{array}$ & $\begin{array}{l}30.8 \\
(1.0-121.5)\end{array}$ & 1.0 & $\begin{array}{l}50.0 \\
(1.0-226.4)\end{array}$ & $\begin{array}{l}1.0 \\
(1.0-72.6)\end{array}$ & 0.2 & $\begin{array}{l}72.2 \\
(2.0-435.8)\end{array}$ & $\begin{array}{l}90.8 \\
(3.6-137.6)\end{array}$ & 0.7 & $\begin{array}{l}108.2 \\
(1.0-195.0)\end{array}$ & $\begin{array}{l}6.3 \\
(1.0-88.9)\end{array}$ & 0.2 & $\begin{array}{l}7.2 \\
(1.0-42.1)\end{array}$ & $\begin{array}{l}50.2 \\
(2.9-196.3)\end{array}$ & 0.08 & $\begin{array}{l}38.4 \\
(1.0-188.1)\end{array}$ & $\begin{array}{l}28.8 \\
(1.0-66.4)\end{array}$ & 0.7 \\
\hline CXCL10 & $\begin{array}{l}2.9 \\
(2.9-1185.1)\end{array}$ & $\begin{array}{l}2.9 \\
(2.9-1061.1)\end{array}$ & 0.7 & $\begin{array}{l}49 \\
(2.9-129.6)\end{array}$ & $\begin{array}{l}2.9 \\
(2.9-525.0)\end{array}$ & 0.9 & $\begin{array}{l}1463.9 \\
(2.9-3716.5)\end{array}$ & $\begin{array}{l}466.6 \\
(2.9-1692.4)\end{array}$ & 0.3 & $\begin{array}{l}76.2 \\
(2.9-1305.5)\end{array}$ & $\begin{array}{l}11.7 \\
(2.9-1818.1)\end{array}$ & 0.9 & $\begin{array}{l}2.9 \\
(2.9-373.4)\end{array}$ & $\begin{array}{l}2.9 \\
(2.9-689.9)\end{array}$ & 0.7 & $\begin{array}{l}2.9 \\
(2.9-1018.1)\end{array}$ & $\begin{array}{l}143.3 \\
(2.9-2116.9)\end{array}$ & 0.4 \\
\hline
\end{tabular}

Sens + Allergic symp $=$ Sensitised women with allergic symptoms $\quad$ Non-sens + No allergic symp $=$ Non-sensitised women without allergic symptoms $*=$ the proportion $(\%)$ of positive values, for mediators with low detectability, when statistically significant differences were observed between groups using comparisons with Mann-Whitney U-test. 
Supplementary Table III. Cat induced induced cytokine and chemokine responses in sensitised women with allergic symptoms and non-sensitised women without allergic symptoms $(\mathrm{pg} / \mathrm{ml})$. Median, IQR $\left(1^{\text {st }}\right.$ and $3^{\text {rd }}$ quartile values) are indicated.

Sens + Allergic symp $=$ Sensitised women with allergic symptoms $\quad$ Non-sens + No allergic symp $=$ Non-sensitised women without allergic symptoms

\begin{tabular}{|c|c|c|c|c|c|c|c|c|c|c|c|c|c|c|c|c|c|c|}
\hline \multirow[t]{2}{*}{ Cat } & \multicolumn{3}{|c|}{$\begin{array}{l}\text { Gestational } \\
\text { week 10-12 }\end{array}$} & \multicolumn{3}{|c|}{$\begin{array}{l}\text { Gestational } \\
\text { week } 15\end{array}$} & \multicolumn{3}{|c|}{$\begin{array}{l}\text { Gestational week } \\
25\end{array}$} & \multicolumn{3}{|c|}{$\begin{array}{l}\text { Gestational } \\
\text { week } 35\end{array}$} & \multicolumn{3}{|c|}{$\begin{array}{l}2 \text { months } \\
\text { post partum }\end{array}$} & \multicolumn{3}{|c|}{$\begin{array}{l}12 \text { months } \\
\text { post partum }\end{array}$} \\
\hline & $\begin{array}{l}\text { Sens + } \\
\text { Allergic } \\
\text { symp } \\
\end{array}$ & $\begin{array}{l}\text { Non-sens + } \\
\text { No allergic } \\
\text { symp }\end{array}$ & $\mathbf{p}$ & $\begin{array}{l}\text { Sens + } \\
\text { Allergic } \\
\text { symp }\end{array}$ & $\begin{array}{l}\text { Non-sens + } \\
\text { No allergic } \\
\text { symp }\end{array}$ & $\mathbf{p}$ & $\begin{array}{l}\text { Sens + } \\
\text { Allergic } \\
\text { symp }\end{array}$ & $\begin{array}{l}\text { Non-sens } \\
+ \text { No allergic } \\
\text { symp }\end{array}$ & $\mathbf{p}$ & $\begin{array}{l}\text { Sens }+ \\
\text { Allergic } \\
\text { symp }\end{array}$ & $\begin{array}{l}\text { Non-sens + } \\
\text { No allergic } \\
\text { symp }\end{array}$ & $\mathbf{p}$ & $\begin{array}{l}\text { Sens }+ \\
\text { Allergic } \\
\text { symp }\end{array}$ & $\begin{array}{l}\text { Non-sens + } \\
\text { No allergic } \\
\text { symp }\end{array}$ & $p$ & $\begin{array}{l}\text { Sens + } \\
\text { Allergic } \\
\text { symp }\end{array}$ & $\begin{array}{l}\text { Non-sens + } \\
\text { No allergic } \\
\text { symp }\end{array}$ & $p$ \\
\hline IL-4 & $\begin{array}{l}2.0 \\
(2.0-2.0)\end{array}$ & $\begin{array}{l}2.0 \\
(2.0-2.0)\end{array}$ & 0.6 & $\begin{array}{l}2.0 \\
* 42.9 \% \text { pos } \\
(2.0-17.9)\end{array}$ & $\begin{array}{l}2.0 \\
{ }^{*} \mathrm{O} \% \text { pos } \\
(2.0-2.0)\end{array}$ & 0.001 & $\begin{array}{l}2.0 \\
{ }^{*} 42.9 \% \text { pos } \\
(2.0-22.6)\end{array}$ & $\begin{array}{l}2.0 \\
* 5 \% \text { pos } \\
(2.0-2.0)\end{array}$ & 0.01 & $\begin{array}{l}4.4 \\
* 55.6 \% \text { pos } \\
(2.0-19.3)\end{array}$ & $\begin{array}{l}2.0 \\
* 9.5 \% \text { pos } \\
(2.0-2.0)\end{array}$ & 0.007 & $\begin{array}{l}2.0 \\
* 44.4 \% \text { pos } \\
(2.0-7.2)\end{array}$ & $\begin{array}{l}2.0 \\
* 8.7 \% \text { pos } \\
(2.0-2.0)\end{array}$ & 0.02 & $\begin{array}{l}2.0 \\
* 37.5 \% \text { pos } \\
(2.0-15.7)\end{array}$ & $\begin{array}{l}2.0 \\
{ }^{*} 0 \% \text { pos } \\
(2.0-2.0)\end{array}$ & 0.004 \\
\hline IL-5 & $\begin{array}{l}29.4 \\
* 71.4 \% \text { pos } \\
(6.9-44.1)\end{array}$ & $\begin{array}{l}6.9 \\
* 8.3 \% \text { pos } \\
(6.9-6.9)\end{array}$ & 0.004 & $\begin{array}{l}23.4 \\
{ }^{*} 55.6 \% \text { pos } \\
(6.9-114.6)\end{array}$ & $\begin{array}{l}6.9 \\
* 20 \% \text { pos } \\
(6.9-6.9)\end{array}$ & 0.04 & $\begin{array}{l}23.6 \\
(6.9-141.2)\end{array}$ & $\begin{array}{l}6.9 \\
(6.9-9.3)\end{array}$ & 0.08 & $\begin{array}{l}13.4 \\
(6.9-108.5)\end{array}$ & $\begin{array}{l}6.9 \\
(6.9-26.8)\end{array}$ & 0.2 & $\begin{array}{l}15.8 \\
{ }^{*} 50 \% \text { pos } \\
(6.9-48.3)\end{array}$ & $\begin{array}{l}6.9 \\
* 12 \% \text { pos } \\
(6.9-6.9)\end{array}$ & 0.01 & $\begin{array}{l}6.9 \\
(6.9-145.2)\end{array}$ & $\begin{array}{l}6.9 \\
(6.9-6.9)\end{array}$ & 0.08 \\
\hline IL-10 & $\begin{array}{l}66.5 \\
(12.8-193.0)\end{array}$ & $\begin{array}{l}87.1 \\
(13.7-200.1)\end{array}$ & 0.7 & $\begin{array}{l}2.4 \\
(2.4-59.1)\end{array}$ & $\begin{array}{l}51.5 \\
(9.1-126.7)\end{array}$ & 0.09 & $\begin{array}{l}37.2 \\
(5.8-183.2)\end{array}$ & $\begin{array}{l}72.1 \\
(15.0-145.1)\end{array}$ & 0.7 & $\begin{array}{l}68.4 \\
(9.6-180.5\end{array}$ & $\begin{array}{l}118.0 \\
(15.9-179.6)\end{array}$ & 0.5 & $\begin{array}{l}120.0 \\
(25.2-143.0)\end{array}$ & $\begin{array}{l}115.0 \\
(20.7-199.3)\end{array}$ & 1 & $\begin{array}{l}57.8 \\
(22.3-134.4)\end{array}$ & $\begin{array}{l}43.0 \\
(2.9-168.5)\end{array}$ & 0.9 \\
\hline IL-13 & $\begin{array}{l}399.9 \\
(165.7-1122.0)\end{array}$ & $\begin{array}{l}99.4 \\
(20.6-319.8)\end{array}$ & 0.05 & $\begin{array}{l}612.5 \\
(98.4- \\
1293.6)\end{array}$ & $\begin{array}{l}68.6 \\
(20.6-413.6)\end{array}$ & 0.05 & $\begin{array}{l}357.3 \\
(132.6-1418.1)\end{array}$ & $\begin{array}{l}187.8 \\
(20.6-595.7)\end{array}$ & 0.3 & $\begin{array}{l}271.3 \\
(87.9-852.0)\end{array}$ & $\begin{array}{l}339.6 \\
(20.6-571.3)\end{array}$ & 1.0 & $\begin{array}{l}332.3 \\
(80.1-498.7)\end{array}$ & $\begin{array}{l}140.7 \\
(31.5-310.7)\end{array}$ & 0.2 & $\begin{array}{l}230.0 \\
(76.0-1558.2)\end{array}$ & $\begin{array}{l}56.7 \\
(20.6-206.6)\end{array}$ & 0.06 \\
\hline IFNy & $\begin{array}{l}43.6 \\
(6.9-127.4)\end{array}$ & $\begin{array}{l}19.9 \\
(6.9-191.5)\end{array}$ & 0.8 & $\begin{array}{l}20.2 \\
(6.9-160.8)\end{array}$ & $\begin{array}{l}6.9 \\
16.9-183.7\end{array}$ & 0.8 & $\begin{array}{l}6.9 \\
(6.9-41.7)\end{array}$ & $\begin{array}{l}12.4 \\
(6.9-126.8)\end{array}$ & 0.2 & $\begin{array}{l}7.8 \\
(6.9-90.3)\end{array}$ & $\begin{array}{l}6.9 \\
(6.9-46.7)\end{array}$ & 0.5 & $\begin{array}{l}6.9 \\
(6.9-101.6)\end{array}$ & $\begin{array}{l}46.7 \\
(6.9-171.3)\end{array}$ & 0.2 & $\begin{array}{l}30.1 \\
(16.3-148.0)\end{array}$ & $\begin{array}{l}6.9 \\
(6.9-84.6)\end{array}$ & 0.2 \\
\hline CCL17 & $\begin{array}{l}123.5 \\
(66.5-567.4)\end{array}$ & $\begin{array}{l}32.1 \\
(1.0-213.1)\end{array}$ & 0.3 & $\begin{array}{l}391.7 \\
(25.6-735.5)\end{array}$ & $\begin{array}{l}45.3 \\
(1.0-154.7)\end{array}$ & 0.08 & $\begin{array}{l}230.8 \\
(51.8-1361.1)\end{array}$ & $\begin{array}{l}97.8 \\
(1.0-366.9)\end{array}$ & 0.2 & $\begin{array}{l}46.2 \\
(1.0-309.8)\end{array}$ & $\begin{array}{l}131.5 \\
(9.5-391.0)\end{array}$ & 0.6 & $\begin{array}{l}75.5 \\
(1.0-315.7)\end{array}$ & $\begin{array}{l}59.6 \\
(1.0-143.2)\end{array}$ & 0.9 & $\begin{array}{l}131.3 \\
(16.0-408.4)\end{array}$ & $\begin{array}{l}25,7 \\
(1.0-112.0)\end{array}$ & 0.2 \\
\hline CXCL10 & $\begin{array}{l}2.9 \\
(2.9-274.9)\end{array}$ & $\begin{array}{l}2.9 \\
(2.9-2.9)\end{array}$ & 0.4 & $\begin{array}{l}2.9 \\
(2.9-578.9)\end{array}$ & $\begin{array}{l}2.9 \\
(2.9-2.9)\end{array}$ & 0.2 & $\begin{array}{l}2.9 \\
(2.9-2.9)\end{array}$ & $\begin{array}{l}2.9 \\
(2.9-2.9)\end{array}$ & 0.7 & $\begin{array}{l}2.9 \\
(2.9-355.7)\end{array}$ & $\begin{array}{l}2.9 \\
(2.9-2.9)\end{array}$ & 0.5 & $\begin{array}{l}2.9 \\
(2.9-2.9)\end{array}$ & $\begin{array}{l}2.9 \\
(2.9-55.6)\end{array}$ & 0.6 & $\begin{array}{l}2.9 \\
(2.9-2.9)\end{array}$ & $\begin{array}{l}2.9 \\
(2.9-60.2)\end{array}$ & 0.4 \\
\hline
\end{tabular}

$*=$ the proportion $(\%)$ of positive values, for mediators with low detectability, when statistically significant differences were observed between groups using comparisons with Mann-Whitney U-test. 